\title{
Don't Leave Home Without Them ${ }^{1}$
}

\author{
David Mendelsohn \\ Patrick Allen \\ Carolyn Coté
}

\author{
Nick Elson \\ Jean Handscombe \\ Catherine Wallace
}

Anyone involved in ESL/EFL teacher-training is aware that a significant number of graduates of these programmes will take up positions teaching English abroad. What is more, it is extremely common for teachers to receive appointments abroad, and for them to be given little or no information about exactly who or what they will be teaching, and under what circumstances, before they actually arrive at their destination. What is more, it is not uncommon for teachers to be hired to teach EFL, but to learn on their arrival, that they are also expected to train teachers of EFL. This is a reality that has existed for many years, and has not shown much sign of improving.

The purpose of this Symposium was to provide some assistance to teachers who find themselves in exactly this situation: they know that they are going to teach English abroad, but know very little else about their responsibilities. Despite the lack of information, they want to take with them the most useful material that they can, particularly given that books, photocopying facilities, etc., will likely be limited where they are teaching. They are also acutely aware that they will be limited in the amount that they will be able to take.

A panel of six experienced teachers/teacher-trainers was assembled to participate in this Symposium, and they were asked to prepare a list of the ten items that they would take with them if they had accepted a position to teach English abroad, and all they knew was that they were going to be teaching adults. Each panelist submitted their annotated list of ten items, and presented their reasons for choosing this list. ${ }^{2}$

As will become evident below, the lists and the panelists' reasons for inclusion or exclusion of different items varied greatly. However, this variation itself is very useful, and will, it is hoped, provide teachers with food for thought as well as providing a very valuable annotated list of some sixty highly regarded and important books.

\section{Patrick Allen, Ontario Institute for Studies in Education}

In compiling my list, I have concentrated on three types of material: (a) books which provide background information on grammar, vocabulary and discourse; (b) 'focused input' designed to encourage error correction and consciousness-raising in the classroom; (c) materials which provide 
motivated activities, topics and themes designed to involve the learner in authentic communication. I am assuming that I will be going abroad to teach adults at the intermediate and higher proficiency levels, since this is where most of my overseas experience has been in the past.

1. Greenbaum, S. and Quirk, R. (1990). A Student's Grammar of the English Language. London: Longman.

A good up-to-date reference grammar with the material arranged for easy consultation is high on my list of priorities, and I have selected the most recent publication in this distinguished series by Randolph Quirk and his colleagues. Whatever type of methodology we use in the classroom, we need a good grammar for background information. There is also the important question of what kind of focused input we need to provide within the context of communicative language teaching. Learners (particularly adults) need access to suitable reference materials, and A Student's Grammar is written at a level which is likely to meet their needs.

\section{Collins Cobuild English Language Dictionary (1987). London: Collins.}

A good dictionary is essential, both to provide background information for the teacher and to encourage the development of metalinguistic awareness in the classroom. In choosing among the many dictionaries available, I have come down in favour of the Collins Cobuild, partly because of its excellent definitions, which are clear and easy to understand, but also because of its authentic citations and its up-to-date coverage of idiomatic English. All the Cobuild volumes are based not on linguists' made-up examples, but on a computerized corpus of spoken and written English which shows how the language is actually used.

3. Edmondson, W. and House, J. (1981). Let's Talk and Talk About It. Munich and Baltimore: Urban and Schwarzenberg.

The subtitle is: 'A pedagogic interactional grammar of English', and the book is based on a systematically-gathered corpus of spoken conversational data, including dialogues between native and non-native speakers. The authors set out to show what native speakers commonly say and do in their everyday talk, and what can go wrong from the learner's point of view. The result is a rich collection of information on various gambits, speech acts and interaction strategies, together with many helpful suggestions on how to incorporate conversational English into teaching programs.

4. Wellman, G. (1989). Wordbuilder: Vocabulary Development and Practice for Higher-Level Students. London: Heinemann.

This recent publication reflects the current interest in vocabulary teaching which derives from the revival of interest in semantics during the seventies. This is an excellent collection of exercises designed to help post-inter- 
mediate students build their active vocabulary. The book is made up of 60 units, each focusing on one area of vocabulary. Within the space of approximately 250 pages the book contains a vast resource of essential vocabulary items, including collocations and idiomatic expressions which are not easy to find in a standard dictionary.

5. Allen, J.P.B. and Widdowson, H.G. (Eds.) (1974-1980). A selection of English in Focus material. Various titles: Oxford University Press.

In recent years there has been a marked revival of interest in what is now known as content-based language instruction, which is essentially a continuation of work done earlier under the heading of English for special purposes. The Focus series was based on the belief that there is a close relationship between the conceptual structure of the subject and the language which is used to express that conceptual content. The ten books in the series provide a wide range of discourse-based language exercises which also explore the characteristics of science and social studies as distinct modes of thought.

6. The Utne Reader: The Best of the Alternative Press. Published bimonthly by LENS Publishing Co., 1624 Harmon Place, Minneapolis.

The present trend is for language teaching to be reconceptualized as a social-interactive process based on the Vygotskian principle of jointly constructed meaning, a process that is essentially dialogic, rather than univocal, in nature. Given this emphasis on dialogue and social interaction, it is important to have something interesting to talk about. Before leaving for my overseas assignment I will certainly arrange a subscription to the Utne Reader. This is a bimonthly publication which contains a variety of articles, fairly simply written, on environmental and social issues of a sort which appeal to students and lead to good discussions.

7. Cornish, Tony (Ed.). Pages from the Press. 85 Gloucester Road, London SW7. Published nine times a year.

This relatively new publication consists of authentic up-to-date material selected from the daily press, accompanied by a variety of exercises graded at elementary, intermediate and advanced levels. The material is published in semi-loose-leaf form so that it is easy to photocopy and use in the classroom. Also, the editors have taken care of copyright problems, so there is no need to feel guilty as you distribute those handouts!

8. Stock, Gregory. Page-a-day Question Calendar. Published annually. Workman Publishing Co., 708 Broadway, New York.

Still on the trail of interesting things to talk about, I would probably find space in my luggage for this page-a-day tear-off calendar. Each page features a talking-point or conundrum which is just the thing for small- 
group discussions of a semi-serious nature. For example: 'Which of the following would you prefer as a total passion and psychological addiction: sex, television, religion, sports, or money?' Who could resist discussing a question like that, even late on a Friday afternoon?

9. Wright, A., Betteridge, D. and Buckby, M. (1984). Games for Language Learning. Cambridge: Cambridge University Press.

The advantage of games is that they help to create contexts in which language is useful and meaningful. They can be used to provide practice in all four skills, for all age groups, and at all levels. For these reasons, I would certainly take some games with me. This book provides an excellent collection of well-known and less conventional ideas, for example picture games, psychology games, memory games, and 'caring and sharing' games. As a result, the book provides a valuable resource which can be used to add interest and variety to almost any language program.

10. Collie, J. and Slater, S. (1987). Literature in the Language Classroom: A Resource Book of Ideas and Activities. Cambridge: Cambridge University Press.

I have found that students often enjoy a literature component in their English program, especially if they spend most of their time studying scientific or technical subjects. I will therefore include Collie and Slater's useful resource book of ideas and activities for handling literature in the ESL classroom. Since literature consists of authentic texts dealing with universal human values, it should be the communicative experience par excellence. With this combination of grammar, vocabulary, carefully selected reading material and topics for spontaneous conversation, I hope to provide a varied and interesting program for my overseas adult students.

\section{Carolyn Coté, School of Continuing Studies, University of Toronto}

Since the only information I have to guide the preparation of this list of ten items is that I will be teaching adults overseas, I have chosen materials that can be easily adapted to accommodate any number of learning/teaching variables and resource texts that will help me do so. As well, I have kept in mind that I may be involved in curriculum design and teacher training. I have loosely organized my ten items according to 3 categories: A) content materials for the classroom and for my own reading/ listening enjoyment $\mathrm{B}$ ) resource texts for teaching/learning and C) professional reference texts for syllabus design and possibly teacher training.

\section{A. Content Materials}

1. Content Modules.

In my opinion, authentic English language material is the most useful 
'item' for language teaching/learning. Since the likelihood of such material being available wherever I was headed is limited at best, I would want boxes of thematically related listening and reading material. I would pack videos (documentaries, sit-coms, talk shows and movies-and pray that the necessary equipment was available), tapes (radio programs, lectures, conversations and songs), newspaper and magazine articles, stories, and pictures on broad themes such as 'Communication', 'Canada', 'Ethical Issues', 'World Problems'. I would want enough material so that students would have as much choice as possible and could choose more specific topics within the parameters of the broader themes. Such 'realia' can be used in any level class, and are especially useful in the multi-level classes one is likely to encounter overseas. I would have some of this material carefully prepared for use immediately upon arrival since it could be a long wait before my other materials arrived.

2. Atwood, Margaret \& Weaver, Robert (Eds.). (1986). The Oxford Book of Canadian Short Stories in English. Oxford: Oxford University Press.

For my own reading enjoyment and for use in the classroom, I would take along this anthology of 41 Canadian short stories ranging from the nineteenth century to the present and covering a variety of styles within the genre. I would also take a lot of pictures to illustrate settings. In my experience, students are extremely interested in Canadian short stories, especially as a way into Canadian culture. I like using short stories because of their practical length and the great variety they offer-in any anthology there's usually something to meet each reader's taste.

I would add a translation of a short story anthology from the country to which I was headed for my reading pleasure and as an introduction into the culture, and again, for use in the classroom-students sometimes find it interesting and useful to work with material that has been translated from their own language.

As a compulsive reader, it would probably be these two anthologies that would keep me relatively sane while immersed in a different culture far from home.

3. Harrington, Laura (Ed.) (1989). 100 Monologues: An Audition Sourcebook from New Dramatists. New York: New American Library.

These short monologues (one or two paragraphs) are an endless source of inspiration for the classroom. They can be used as a resource for interpretive reading, a challenging stimulus for writing, and performance material for talking or pronunciation. This text also brings authentic North American culture into the EFL classroom and fosters stimulating discussions.

\section{B. Resource texts for teaching/learning}

4. Maley, Alan and Duff, Alan. (1982). Drama Techniques in Language 
Learning: A resource book of communication activities for language learners. Cambridge: Cambridge University Press.

I'm a real champion of using drama in any ESL classroom: it's fun, it's motivating, it integrates all the skill areas, and it involves students in using the target language in creative and meaningful ways. Drama activities loosen up more inhibited students and, perhaps paradoxically, focus fluent students on form. In this text, a brief introduction to using drama in the ESL classroom is followed by activities ranging from word-play and problem-solving to interpretation and creation. I've successfully used many of these activities in elementary to advanced classes.

5. Gairns, Ruth and Redman, Stuart. (1986). Working with Words: A guide to teaching and learning vocabulary. Cambridge: Cambridge University Press.

Building vocabulary is high on the priority list of language learners everywhere. In an EFL environment in particular, the learners are dependent on the vocabulary you bring into the classroom. This book provides a practical guide to selecting, organizing, and teaching vocabulary items. A brief summary of relevant linguistic and psychological theory is followed by dozens of vocabulary activities to use or adapt, and work sheets that include copyright permission. The final chapter suggests ways of supplementing the vocabulary component of coursebooks-particularly useful when you are going into an unknown situation where you may have to use prescribed texts.

6. Ellis, Gail and Sinclair, Barbara. (1989). Learning to Learn English: A Course in Learner Training. Cambridge: Cambridge University Press.

A systematic, practical and flexible guide to help ESL learners determine the learning strategies/styles that are best for them. The exercises are designed to encourage learners to take on more and more responsibility for their own language learning by taking them through step-by-step exercises that help them determine what kind of language learner they are, require them to build on what they already know, and help them assess their progress. Ideally, this text would enable students to continue learning long after you have gone as it very much encourages learner responsibility and self awareness. As well, the exercises, the follow-up discussions, and the analyses very much involve students in authentic classroom communication. The 'Teacher's Book' provides a good, brief introduction to some of the theoretical issues and is a useful guide to the Learne's text.

7. Fournier, Carol Ann. (1990). Open for Business: Communication Activities for Students of English. New York: Newbury House Publishers.

For those students who are interested in business English, and for those 
instructors without a business background, this text offers writing, talking and listening activities related to such areas as sales, finance, banking and accounting. Besides offering a good variety of communicative activities, the text includes models for different types of memos and letters, and lots of work-related vocabulary. The last unit involves guidelines for the completion of a Business Project chosen, designed and implemented by the students; this project would work well in an EFL environment as it directs the students towards work issues in their own countries.

8. Celce-Murcia, Marianne and Larsen-Freeman, Diane. (1983). The Grammar Book: An ESL/EFL Teacher's Course. Rowley: Newbury House Publishers, Inc.

This grammar text covers most of the material that comes up in the classroom in a comprehensive and accessible fashion-it explicates grammar to me in a way that I can easily transfer to the class. Each chapter includes practical teaching suggestions but I particularly like the puzzle-like exercises designed to engage the reader.

\section{Professional Reference Texts}

9. Brinton, Donna M., Snow, Marguerite Ann and Wesche, Marjorie Bingham. (1989). Content-Based Second Language Instruction. New York: Newbury House Publishers.

Because I would want to use content-based language instruction wherever possible, I would want to pack this book to supplement my content modules. The authors developed the text to serve as a "resource guide to those involved in developing and implementing [ESL and EFL] content-based courses" and, therefore, offer guidelines, practical suggestions, and samples for selecting and designing courses, adapting and developing materials, and evaluating students. As well, the text examines three contentbased teaching models ('theme-based', 'sheltered', and 'adjunct') illustrated by programmes from the United States, Canada, Berlin and China. This comprehensive text could well be used in teacher training programmes.

10. Nunan, David. (1988). Syllabus Design. Oxford: Oxford University Press.

Teaching in unfamiliar situations demands a flexible approach to syllabus design. This text explores ways of evaluating, modifying and adapting the syllabuses with which you might find yourself working and acts as a practical guide for examining needs analysis, setting goals and objectives, and selecting and grading content and learning tasks. As well, Nunan sets frequent exercises to actively involve the reader in the process of syllabus 
criticism and design. This text is a challenging and thought-provoking resource useful in any teaching situation.

\section{Nick Elson, York University}

Few of these selections deal directly with classroom strategies. Rather, they represent to me a fundamental reality about language teaching. To be effective and to grow as a teacher one needs techniques but also inspiration and insights into those forces that shape what we end up doing in the classroom. Several of my selections therefore deal with the larger context-social, political, economic, cultural, and pedagogical-that sets up those forces whose ripples eventually touch the classroom. Some others look at the nature of language and language teaching and learning, and others are simply there to remind me that when things get tough there is always, at the heart of what we do, the pleasure of working with language.

1. Naisbitt, John, Patricia, Aburdene. (1990). Megatrends 2000: Ten New Directions for the 1990's. New York: William Morrow and Co.

In spite of a certain shallowness and trendiness, there is much to be said for this book. It forces you to wonder whether what the authors are suggesting is supported by your own observations and experience. It provokes you to step away from the busy flow of daily life and to look at what trends there are that might influence one personally and professionally. The writers offer, for example, some interesting thoughts on the role of technology in our lives particularly as it empowers the individual.

2. Drucker, Peter F. (1989). The New Realities. New York: Harper and Row.

Drucker is an interesting person because although known primarily as a writer on business related topics he is a thoughtful, well educated and intelligent observer who frequently comments on the form and relevance of education. Although interested in somewhat the same ground as Megatrends 2000 Drucker produces a more complex and far-reaching book. He structures his analysis within three main categories: government and politics, economics and business, and what he calls society and world view. $\mathrm{He}$ calls for "serious discussion of the social purpose and responsibility of education in the new reality of the knowledge society." (242)

3. Smith, Frank. (1986). Insult to Intelligence: The Bureaucratic Invasion of Our Classroom. New York: Arbor House.

Smith is always a good read and has a perception of the learner that is a good antidote to some of the wilder notions that exist in education. Insult is the best attack on the "drill and kill" school of thought in education that I have read. There is far too much in the book to even attempt to sum- 
marize, but his primary topics include how we learn, what he calls the "nonsense industry"-those publishers and experts who produce materials and exercises that make no sense at all-administrative influences over the teaching-learning process, testing-which comes in for a particularly bad time-the good teacher, and computers in education.

4. Esling, John H. (Ed.). 1989. Multicultural Education and Policy: ESL in the 1990s. Toronto: OISE Press.

Produced as a tribute to Mary Ashworth, this book is organized into three main sections: Issues in Policy Development; Directions in Research and Teacher Effectiveness; and Instructional Implementation. Contributors include Jim Cummins, Jean Handscombe, Peter Strevens, Merrill Swain and Alister Cumming. Lily Wong Fillmore, Scott Enright, and of course Mary herself. This book reminds me of the extraordinary range and complexity of our profession, but also of the excitement of working out the problems that we face.

5. Ashworth, Mary. (1985). Beyond Methodology: Second Language Teaching and the Community. Cambridge: Cambridge University Press.

On the back cover of the previous book, Multicultural Education and Policy Mary Ashworth is depicted sitting on a tractor, wearing a cowboy hat and a TESL Canada t-shirt. If you read Beyond Methodology understand that the image thus created is appropriate. The book's pages are full of the energy, insight and fierce pragmatism that have allowed Mary Ashworth to make the contribution that she has to the development of TESL as a profession in this country and others. The book places the language teacher firmly in the forefront of the change making process and makes it clear that no-one else is going to make the changes that are needed.

6. Ovando, Carlos J.; Collier, Virginia P. (1985). Bilingual and ESL Classroom: Teaching in Multicultural Contexts. New York: McGraw Hill.

I find the scope of this book extraordinary. It looks at the student, the historical and political context of bilingual and ESL classrooms, language, techniques, culture, music, art, maths and science in relation to the ESL and Bilingual classroom, assessment and more. It's a book one can dip into from time to time just for a shot of inspiration or to find a theory or a suggestion to look at in light of one's own situation.

7. Wells, Gordon. (1986). The Meaning Makers: Children Learning Language and Using Language to Learn. Portsmouth, N.H.: Heineman.

This is a book that teaches us to listen, really listen, to the way language is used. It's an old lesson for language teachers, but under the pressure of 
meeting the demands of the job, classroom, administrative, and professional, it's easy to drift away from that familiarity with real language, in real contexts, that keeps us aware of what it is we are really doing. Behind the transcriptions of speech and the analysis and observation is a genuine admiration on Wells' part for those who are struggling in various ways to make meaning with language.

8. Brown, H. Douglas. (1987). Principles of Language Learning and Teaching. 2nd ed. Englewood Cliffs, N.J. Prentice-Hall.

This it the best broad overview of second language teaching and learning, both stylistically and in content. These are the theoretical roots of what we do. There are certainly books that deal with many of these aspects in more detail, but never more clearly and thoughtfully. Whether "Does lateralization signal the death of LAD?" or "How do you 'learn' intuition?" are questions that trouble you or not, they're just two of many that the book raises to the reader's benefit.

9. Mohan, Bernard, A. (1986). Language and Content. Reading: Mass.

I have always liked this book because it helped to make concrete for me some of the things I knew or suspected about language teaching and learning but needed the re-assurance of someone else's analysis to confirm. We did invent meaningless language, and we are still not free from occasional excursions into that swamp, as Smith points out in Insult to Intelligence. Mohan reminds us why language and meaning are two sides of the same coin.

10. Sarnoff, Jane. Ruffins, Reynold. (1981). Words: A Book about the Origins of Everyday Words and Phrases. New York: Charles Scribner's Sons.

We need a book or two that reminds us that language is history, it's culture, it connects us not only to the immediate world around us but also offers us a peek down the long tunnel of time to the days when times-and language-were very different. And the movement of the word nicewhich meant silly or simple in the 12th century, came to mean "foolish and stupid in the 13th" "too free and open" in the 14th. "Shy" in the 17th, "dainty and precise" in the $16 \mathrm{th}$, and, around the $18 \mathrm{th}$, the meaning we give it today-reminds us that language is living and everchanging.

\section{Jean Handscombe, North York Board of Education}

Since the only information which I have about my hypothetical position overseas is that I will be teaching adults, I have chosen fairly general resources to include in my list. I have grouped them in three broad categories. 
A) Materials which will give me an "in" into the culture of the country in which I am teaching.

William Foote Whyte's book, Learning from the Field: a Guide from Experience $^{l}$ is a guide to doing field work and then figuring out what you have learned in the process. I would enjoy trying out some of the ethnographic techniques which he illustrates, and would try to heed his warnings about what I might do wrong or misinterpret as a stranger in an unfamiliar setting.

I have always found the cuisine of a country to be a good introduction to many aspects of its history, physical and social geography, climate and culture. It also seems to be a non-threatening topic of discussion and one of interest to a wide cross-section of any community. I would be sure to pack the relevant title from the 26 volume set of Time-Life Books of Foods of the World. ${ }^{2}$ It would provide me with a solid background to further explore with local inhabitants what foods are important to them and why as well as what regional differences exist within the country.

\section{B) Materials which will provide reference material both for myself and my students.}

Since in most countries of the world nationals of those countries are already in place teaching English, I suspect that, as a native English-speaking expatriate, I might be more appropriately employed in teacher preparation programmes. My selection reflects that likelihood.

Focus on the Language Learner ${ }^{3}$ is based on the assumption that no two classes are the same and that, consequently, an essential skill for all language teachers is to learn how to do an analysis of learner needs, involving the learners in that process, and then how to plan a programme to meet the needs so identified. Tarone and Yule have a classroom-based and learner-focussed view of language teaching and learning. Their book contains many practical suggestions and excellent guidance as to further reading.

Understanding Second Language Acquisition ${ }^{4}$ by Rod Ellis is a comprehensive review of the "state of the art" in second language acquisition. It would remind me of what to look for in learner behaviour when I myself teach or when I am observing others.

Since it is likely that the adults with whom I am interacting will have a thousand and one questions about the grammar of English, I would want to take at least one book on that topic. In fact, more than one would be better in order to illustrate that there is more than one way to describe the language. I like The Grammar Book ${ }^{5}$ partly because it does draw on several descriptive models-largely transformational, but also traditional and case grammar and discourse analysis, in instances when these seem 
more helpful. It provides suggestions as to how to convey grammatical knowledge by other means than explicit lecturing on rules and never loses sight of the pragmatics of English. It is not the kind of book that one would necessarily want to read from cover to cover, but its helpful indexes allow easy access to information relevant to specific problems which arise, a feature which I would find particularly useful when I wanted my students to find answers to the questions they raised.

In similar vein, I would want to have a good dictionary with me. I chose Collins Cobuild English Language Dictionary ${ }^{6}$ because it is based on a modern corpus of written and spoken English, draws attention to the most common words of English, uses "real" citations, and is written in clear, easy to understand English.

David Crystal's The Cambridge Encyclopedia of Language ${ }^{7}$ is a rich compendium of information about the languages of the world, how they are learned and used, and how they change. Its multilingual focus would help counteract any notions that English is somehow the only language of importance and would allow for comparison and contrast between English and other languages.

Evaluation of student progress is an essential element of any teacher's task. To help me do this well, I would take with me The Assessment of Second Language Proficiency: Issues and Approaches ${ }^{8}$. In this slim volume, Goeff Brindley seems to me to get right to the heart of what is important in second language proficiency assessment.

\section{C) Materials which would be sources for language lessons.}

There is much source material for good language lessons in every one of the books which I have so far described. They are all written in the kind of prose style which aims at communicating with readers rather than baffling them. The cook book, with its descriptions of foods and places with which the learners would no doubt be familiar, would allow even low proficiency students to begin to read in English. Focus on the Language Learner ${ }^{3}$ contains many ideas for encouraging learners to be language "detectives", exploring a variety of settings in which language is used. If my students had absolutely no preferences as to what English they wanted to learn, then I think I would design their course out of Crystal's encyclopedia. In addition, I would take along a few books whose topics held universal interest. For example, the Foreword to Games of the World ${ }^{9}$ states, "These pages are filled with ideas, information, instruction and suggestions from all corners of the world. They show us that games know no boundaries, that when it comes to play-to this basic expression of human life-there is only one world." The functions of English which could be practised using this topic are many and varied-description, 
instruction, justification to name but a few. Where the Forest Meets the $\mathrm{Sea}^{10}$ is a beautifully illustrated book which follows a young boy and his father on a visit to a tropical rain forest in North Queensland, Australia, and raises the disturbing prospect of its future destruction. I could see using this book with its simple text as the trigger for a complex unit on ecology.

I would also pack two other items. My UNICEF calendar would provide me with a place to keep a daily log of my activities and reactions as well as over 50 magnificent coloured photographs of the world's children which I would use as discussion starters. Lastly, I would take with me a list of the names and addresses, phone, fax and e-mail numbers of all my friends and colleagues-my lifeline for obtaining all the other resources I would need once I knew more about my students and what they wanted me to help them learn.

The following provides complete bibliographical details of the items cited above.

\section{BIBLIOGRAPHY}

1. Whyte, William Foote. (1984). Learning from the Field: A Guide from Experience. Beverly Hills: Sage Publications.

2. Foods of the World. (1968). New York: Time-Life Books.

A set of 26 volumes which introduces the world's cuisines within the context of the culture, geography, history and climate of the different areas.

3. Tarone, Elaine and Yule, George. (1989). Focus on the Language Learner. Oxford: Oxford University Press.

A classroom-based and learner-focussed view of language teaching and learning, with many practical suggestions and excellent guidance as to further reading.

4. Ellis, R. (1986). Understanding Second Language Acquisition. Oxford: Oxford University Press.

5. Celce-Murcia, Marianne and Larsen-Freeman, Diane. (1983). The Grammar Book. Rowley: Newbury House.

6. Collins Cobuild English Language Dictionary (1987). London and Glasgow: Collins.

7. Crystal, David, (Ed.). (1987). The Cambridge Encyclopedia of Language. Cambridge: Cambridge University Press.

8. Brindly, Geoff. (1986). The Assessment of Seond Language Proficiency: Issues and Approaches. National Curriculum Resource Centre. Adult Migrant Education Program. Adelaide, Australia.

9. Grunfeld, Frederic V. (1975). Games of the World. Zurich: Swiss Committee for UNICEF. 
10. Baker, Jeannie. (1987). Where the Forest Meets the Sea. New York: Greewillow Books.

\section{David Mendelsohn, York University.}

When I drew up my list, my basic premise was to take the 10 items that I could get maximum mileage from. I have grouped my items into 6 groups.

\section{A. Reference and Theoretical Texts}

1. Quirk, Randolph and Sidney Greenbaum. (1973). A University Grammar of English. London: Longman.

I would not leave home without a reference grammar, and chose the Quirk and Greenbaum over The Grammar Book because I find it more accessible to me and to teachers who I might be working with. For the same reason, I also chose the University Grammar of English over the larger text by the same authors.

2. Stevick, Earl. (1989). Success with Foreign Languages: Seven Who Achieved it and What Worked for Them. Englewood Cliffs, N.J.: PrenticeHall International.

This is an outstanding book from which I have derived a great deal of stimulation and inspiration. It describes seven case studies of very successful foreign language learners and analyzes what they did and what strategies they used, and then maps these onto existing methodologies. It is a book that triggers new ideas every time I pick it up! Stevick's commentary is brilliantly insightful, and the potential applications are limitless.

3. Prator, Clifford and Betty Wallace Robinett. (1985). Manual of American English Pronunciation. Fourth Edition. New York: Holt, Rinehart and Winston.

This book is an interesting blend of theory and practice. It is an excellent book on three counts: it is excellent as a reference, it is excellent for teacher-training, and it provides excellent source material for developing Pronunciation materials. One reservation must, however, be voiced: there is, in my opinion, too much emphasis on the production of the individual sounds, and too little emphasis on stress, rhythm and intonation, and this imbalance should be redressed when developing any Pronunciation course.

\section{B. Teacher-Training and Methodological Material.}

4. Brown, H. Douglas. (1987). Principles of Language Learning and Teaching. Second Edition. Englewood Cliffs, N.J.: Prentice-Hall. 
This book is, first and foremost, very readable. It is a very good and very comprehensive text for any teacher-education course that I might be involved in, and it also has the added value of providing a very extensive bibliography.

5. Bell, Jill. (1988). Teaching Multilevel Classes in ESL. Agincourt, Ont.: Dominie.

Brown, above, provides theoretical material, and Bell's book on teaching multilevel classes is very down-to-earth, and full of classroom suggestions. In addition, Bell's book is very comforting and supportive for the often overwhelmed teacher of the multilevel class, in its recognition of the limitations of what we as teachers can do, and in its very sensible suggestions as to how to solve some of the classroom difficulties we are bound to face.

\section{Reading Material.}

6. Mandel, Eli and David Taras, (Eds.) (1988). A Passion for Identity: An Introduction to Canadian Studies. Scarborough, Ont.: Nelson Canada.

This is a fine collection of readings on Canadian identity and on regional identities within Canada. It provides a very good Canadian source for real Social Science academic material-something we are very likely to need.

\section{Communicative Speaking Material.}

7. Mendelsohn, David, Rose Laufer and Jūra Seskus. (1984). Functioning in English. Agincourt, Ont.: Hodder and Stoughton (Dominie).

This is a text that I know intimately and one that provides communicative activities, functionally organized, for the low-intermediate level student. However, personal experience has shown that this material can easily be adapted for use with higher level students. In addition, there is a Teachers' Manual which not only makes it more useful to colleagues who are not very confident about their own English and/or this approach, but the Teachers' Manual also serves as a "mini-methodology" on how to teach Speaking functionally and communicatively.

8. Ur, Penny. (1983). Discussions that Work: Task-Centred Fluency Practice. Cambridge: Cambridge University Press.

This book, like Ur's Listening book below, is an invaluable resource for any teacher of Speaking, and I certainly would not "leave home without it!" It contains a very broad selection of interesting and communicative activities that can be adapted and used in any communicatively-based Speaking programme. It abounds in ideas for group-work. A refreshing 
additional feature of this book is that it has parallel activities suitable for adults and for children.

\section{E. Pronunciation Material.}

9. Gilbert, Judy. (1984). Clear Speech. Cambridge: Cambridge University Press.

This book, soon to come out in an updated edition, is, in my opinion, undoubtedly the very best textbook that I know for the teaching of Pronunciation. It is available as a Students' Book and as a Teacher's Book. It recognizes the primacy of stress, rhythm and intonation over the individual sounds, which is, unfortunately, rare in Pronunciation texts. It concentrates on the principle which I wholeheartedly endorse, that in teaching Pronunciation, we should concentrate on those features in which we can effect maximum change and improvement in the shortest possible time. Moreover, the practice provided is always contextualized and meaningful, and recognizes the inescapable link between Listening and Pronunciation.

The new edition also contains a very well thought-out diagnostic test, which will be invaluable to Pronunciation teachers.

\section{F. Listening Comprehension Material.}

10. Ur, Penny. (1984). Teaching Listening Comprehension. Cambridge: Cambridge University Press.

My praise for this book is parallel to my praise for Ur (1983) on Speaking, above.

This book has a brief, but very sensible first section on some of the basic principles of teaching Listening Comprehension, but its major strength is the longer sound section which abounds in good ideas for the classroom.

\section{G. Writing Material.}

Being limited to 10 items, I was unable to include even one text for each of the skill areas. I chose not to take a book on the teaching of Writing, as there is no one Writing book that I "love dearly", and my experience over the past several years has been that when I teach a Writing course, I draw on several different sources, and am not very happy with any one single text.

\section{Catherine Wallace, Ealing College of Higher Education}

When I was asked to participate in the Symposium my first thought was 'what did I take to the Congo'? A few years ago I had, at short notice, to 
select material for a group of teacher trainees whose background and language level were largely unknown to me and for a teaching context where we could not rely on the availability of equipment and materials. We had to think in terms of taking with us a few key resources that could generate a wide range of classroom activities.

My second thought was to consult my students doing a Masters' course in ELT at Ealing College and who have all taught in many different parts of the world. I am indebted to them for some of the ideas which follow, though decided against others such as 'Swiss Army Knife' (an all-purpose survival tool to cope with practical emergencies); and party dress (to raise ones own morale) as really being beyond our brief, however broadly interpreted!

The party dress idea however, is not entirely frivolous as one of the roles of any item that one might take to a new teaching post, in possibly a remote part of the world, is to offer inspiration, excitement and entertainment. A favourite book of poems might serve this purpose for oneself as well as providing a source of teaching material and this is therefore on my list.

Another criterion is classroom exploitability. Teaching material must have the potential to generate a range of different activities for students of different language levels. It seemed to me that resources or 'ideas' books would serve this purpose better than specific course materials.

A third criterion is that the material could be used as a professional resource on which fellow teachers as well as students might draw, especially in the possible absence of library facilities.

All these factors guided my thinking in the selection of my ten items. I shall focus on the first six on my list (which appears below), simply mentioning the final four as examples of the kind of realia we can collect ourselves-and to remind us that we do not need to be entirely dependent on commercial material.

1. The Guardian Weekly would offer a continual supply of topical newsstories of international interest, addressing the need to provide challenging content for adult learners. Adults welcome the opportunity to read authentic non-trivial non-parochial material in English, even if the teacher may need to provide structured access to it in the case of early and intermediate learners.

2. Practical English Usage This was mentioned by nearly all my Masters' students and is one of the most popular student reference grammars in Britain. It has the advantage of not being merely a grammar but includes lexical and idiomatic features of English as well as matters of style and language varieties. Differences between British and North American usage are given particular attention for instance. 
3. A Comprehensive Grammar of the English Language This is the fullest grammar with which I am familiar. One essential resource (a good dictionary is clearly another) is a reference grammar to which one can turn for a much fuller explanation of a grammatical point than a grammar like Swann's is able to offer. A grammar of this kind is an essential tool of the trade.

4. Writing by Tricia Hedge I selected this as my key resource book for several reasons. Firstly and most generally, it seems that in a teaching context where material resources may be scarce one must maximize the skills of human resources-in particular, our learners. Thus if one cannot readily find texts to read, then the students can write their own-and write them for other students too. I selected Hedge's book specifically because it is an excellent example of the relatively new genre of 'theory to practice' books where current ELT theory is underpinned by excellent examples of practical tasks; secondly, the tasks can be adapted for use with all language levels; thirdly, the book is an endless source of good ideas about task design-not just for writing but for work with the other language modes.

5. The Fat Black Woman's Poems I wanted to include fiction as I think literature has been underrated as a teaching resource--particularly poetry. I chose the poetry by Nicholls, a young British black writer, partly to challenge the stereotyped canonical view of English literature which typical literature collections offer. Young contemporary writers are able to offer insights into lifestyles and values in Britain-or in Canada or the USA-in a succinct and pithy way, and the themes they deal with are more likely to be relevant to young adults in other cultural contexts.

6. Making Stories, Changing Stories and Reading Stories These books do not just feature a whole range of story genres, but include tasks which encourage students to interpret stories from different cultural perspectives. Different versions of stories are given to encourage students to see how stories are constructed at different times and places with particular readers in mind. I conclude with one-unorthodox-version of Red Riding Hood given in 'Changing Stories'

One afternoon a big wolf waited in a dark forest for a little girl to come along carrying a basket of food to her grandmother. Finally a little girl did come along and she was carrying a basket of food. 'Are you carrying that basket to your grandmother?' asked the wolf. The little girl says yes, she was. So the wolf asked her where her grandmother lived and the little girl told him and he disappeared into the wood.

When the little girl opened the door of her grandmother's house she saw that there was somebody in bed with a nightcap on. She had 
approached no nearer than twenty-five feet from the bed when she saw that it was not her grandmother but the wolf, for even in a nightcap a wolf does not look any more like your grandmother than the Metro-Goldwyn lion looks like Calvin Coolidge. So the little girl took an automatic out of her basket then shot the wolf dead.

Moral: It is not so easy to fool little girls nowadays as it used to be (version by James Thurber, 1939)

The following is my list of the items briefly annotated with complete bibliographical details:

\section{BIBLIOGRAPHY}

1. Subscription to 'Guardian Weekly' (incorporating Le Monde).

This is an airmail edition of selected articles from the British newspaper: 'The Guardian', as well as translations of articles from 'Le Monde'. It could offer the possibility of a continual supply of topical news stories of international interest, to be adapted or simplified for early L2 learners.

2. Swann, Michael. (1980). Practical English Usage. Oxford: Oxford University Press.

This is one of the most popular reference books for intermediate to advanced learners. It has the advantage of being presented alphabetically, like a dictionary, and including lexical and idiomatic features of English as well as syntactic ones and would be a useful resource for students as welll as teachers.

3. Quirk, R., Greenbaum, S., Leech, G. and J. Svartvik. (1985). A Comprehensive Grammar of the English Language. London: Longman.

This offers a very full description of contemporary English grammar and is therefore essential as a teacher resource.

4. Hedge, Tricia. (1988). Writing. Oxford: Oxford University Press.

This is an excellent teacher resource book which not only gives numerous examples of writing tasks for all levels of learner but offers insights into task design for all the language modes.

5. A collection of poems by several or one contemporary poet. An example might be: The Fat Black Woman's Poems by Grace Nichols. (1984). London: Virago Press.

Some of these poems are written partly in Creole and would therefore offer students some access to varieties of written English other than standard. Also they have the potential to generate student poems dealing with similar themes but related to their own cultural context.

6. A set of three books on stories: Making Stories, compiled and written by Bronwyn Mellor and Mike Raleigh with Paul Ashton (1984); 
Changing Stories, compiled and written by Bronwyn Mellor with Judith Hemming and Jane Leggett (1984); Reading Stories by Bronwyn Mellor, Marnie O'Neill and Annette Patterson. Sutherland Street, London SW1 4LH: The English Centre.

This material consists of sets of stories and story extracts with accompanying tasks. Though designed for $\mathrm{L} 1$ readers it is excellent also for L2 learners. The stories are drawn from around the world; the tasks encourage learners to analyze and challenge typical story genres, from simple folk tales to literary texts by well-known writers. It can also enerate from students' examples of stories familiar with their own culture.

7. Photograph album with a large set of photographs or postcards of people, places or events from around the world. Photographs can generate oral work with early L2 learners but also be used in many different kinds of tasks for more advanced learners.

8. A collection of native speaker talks recorded on cassette. This might feature speakers of both sexes, a range of ages and of different regional, national, social class and ethnic backgrounds, and cover a range of spoken genres, topics and monologue/dialogue.

9. A collection of 'realia' from a British context-but offering comparison with the L2 setting. This might consist of, e.g. bus tickets, notices, maps, brochures and advertisements and employment or health.

10. A scrapbook of newspaper cuttings of 'human interest' stories with universal themes. This could be a good resource for discussion, comparison or cultural perspectives and/or student rewriting and simplifying for a different audience.

\section{Conclusion}

Varied though the six panelists' lists may be, it is possible to "tease out" the criteria that were used in making the selections:

i. Reference texts

ii. Versatile ESL/EFL texts for teaching different areas and skills of English

iii. Appropriate reading material (fiction or non-fiction, prose or poetry) not written for non-native speakers

iv. Ideas for games

v. Favourite theoretical texts for use in possible teacher-training and/or for professional nourishment

vi. Canadian material

vii. Favourite books for personal "mental health"

viii. Pictures, realia, recordings. 
This list, coupled with the list of items themselves will, we hope, be of some assistance to teachers faced with the dilemma of what not to leave home without!

\section{NOTES}

1. This was presented as a half-day Symposium at the TESL Ontario Conference in Toronto, November 1990.

2. This Symposium is modelled on "The Teacher's Desert Island Survival Kit", presented by David Mendelsohn, Palmer Acheson, Janet Dawson, Richard Handscombe, Maureen Hynes, Francis Mangubhai, Jūra Seskus, and H.H. (David) Stern. That Symposium was presented at the TESL Ontario Conference, November 1985, and published in the TESL Canada Journal, Special Issue 1, November 1986, 135-152. 